\title{
Timber Floors and Strengthening Techniques (Illustrated With a Numerical Example)
}

\author{
Žiga UNUK ${ }^{1}$ \\ Miroslav PREMROV ${ }^{2}$ \\ Vesna ŽEGARAC LESKOVAR ${ }^{3}$
}

\begin{abstract}
The trend of renewing old masonry buildings and provision of new housing, public and other areas without using new building blocks is becoming increasingly important to ensure the conformity of the renovated buildings with the current technical regulations. One compliance aspect is the load-bearing function, which to a large degree depends on the floor structures. As old masonry buildings often have timber floors, the purpose of this article is to provide insight into the field of timber floor strengthening. Thus, the evolution of floor structures is briefly presented, and common types of timber floors are provided. Furthermore, the weight of different timber floor fillings is studied in relation to the prescribed imposed loads. Measures for strengthening old timber floors are introduced separately in view of vertical and horizontal strengthening. Additionally, a classic timber floor and a timber-concrete composite floor are analyzed regarding current building standards in the European Union, the Eurocodes.
\end{abstract}

Keywords: Floor structures, timber floors, strengthening, timber-concrete composite, Eurocodes.

\section{INTRODUCTION}

A frequent situation in building renewal is the change of the category of use, which can in certain cases lead to the requirement imposing higher incident loads and consequently to necessity for structural improvement of the existing structure. Nonetheless, even a change in a standard can increase the minimum incident load, which can be related to the progress of the housing culture and/or policy changes. In the studied case, special attention must be paid

Note:

- This paper has been received on March 22, 2018 and accepted for publication by the Editorial Board on December 24, 2018.

- Discussions on this paper will be accepted by September 30, 2019.

- https://dx.doi.org/10.18400/tekderg.408857

1 University of Maribor, Faculty of Civil Engineering, Transportation Engineering and Architecture, Maribor, Slovenia - ziga.unuk@um.si - https://orcid.org/0000-0001-6143-2569

2 University of Maribor, Faculty of Civil Engineering, Transportation Engineering and Architecture, Maribor, Slovenia - miroslav.premrov@um.si - https://orcid.org/0000-0003-3717-8235

3 University of Maribor, Faculty of Civil Engineering, Transportation Engineering and Architecture, Maribor, Slovenia - vesna.zegarac@um.si - https://orcid.org/0000-0002-0774-0920 
to floor structures as a building element which bears the incident loads and transfers them to the adjacent walls. Since timber floors present a significant part of the existing building stock (for example in Slovenia [1]), acquirement of existing timber floor data and strengthening measures is crucial for planning effective building renewal strategies.

Regarding the strengthening problem, timber floors can be arranged into two categories. The first category represents timber floors that have no importance for the cultural heritage and the second category represents timber floors of historical and cultural interest. The strengthening techniques for the first group are controled only with the owners wish or solely by economic reasons, whereas limitations for the second group regard the reversibility, the compatibility, the minimum level of intervention and fulfillment of internationally accepted requirements regarding historic architecture [2].

The strengthening measures for timber floors can be split into strengthening techniques for vertical ("out of plane") loads and horizontal ("in-plane") loads [3]. Especially the timberconcrete composite (TCC) section has gained importance as a new structural element and as a strengthening technique in the past years [4], as it strengthens the "out of plane" and "inplane" behavior of the timber floor simultaneously. Instead of the concrete part of the TCC section, additional timber elements in the form of cross-laminated timber are often used, which presents a dry technique for forming composite cross sections and is therefore preferred for timber floors of historical or cultural interest $([2,3,5,6])$. Other strengthening techniques involve the use of additional tensile or bending elements connected to the existing timber joists.

Beside increased incident loads, time imposed timber damage can be a reason for strengthening measures, although it is often an argument for replacement of the timber floor with a reinforced concrete floor. Floor vibrations are also an essential criterion for evaluating floor structures but are already positively influenced with strengthening measures for ultimate and deflection limit states which are not covered in this article.

Irrespective of the article's subject being only load-bearing capacity, there are also other important timber floor technical criteria, such as sound insulation, fire safety and thermal conductivity. They must not be ignored when planning timber floor renovation, but they also are not considered in this study.

The first part of this article briefly presents the evolution of floor structures and timber floor types in Central Europe, although the validity of the findings for other territories is not excluded. Attention is also given to timber floor filling weights. In addition, an overview of timber floor strengthening techniques is provided. The second part of this article includes a numerical comparative case study of a classic timber floor and a timber-concrete composite floor. The research focuses especially on the acquirement of existing timber floor geometry; whereas the essential contribution of the numerical study lies in the load-bearing capacity limitations of existing timber floors and TCC floors with existing timber floor joist geometry.

\section{THE EVOLUTION OF FLOOR STRUCTURES}

According to [7], Central European floor structures until the $19^{\text {th }}$ century can be arranged into three groups: 
- $\quad$ Timber floors with joists without spacing (Fig. 1a)

Due to a higher load-carrying capacity, they were often used for the upper floors, because they provided a higher fire safety as they could carry the loads resulting from a demolished roof structure, possibly as a result of a fire. Due to the dense arrangement, they also provided a significant obstacle for fire propagation.

- Classic timber floor with timber joists with spacing (Fig. 1b)

They were used for floors between the ground and upper floor. There are many subtypes which only differ in the sense of different arrangements of floor paneling and filling between joists.

- Vaults (vaults, vaults between iron beams) (Fig. 1c)

Vaults were usually used on lower floors, cellars and over staircases.[7]

(a)

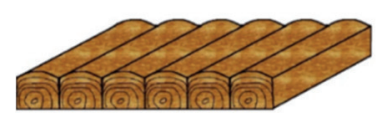

(b)

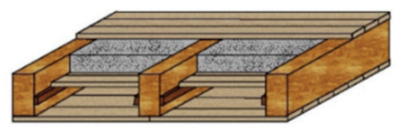

(c)

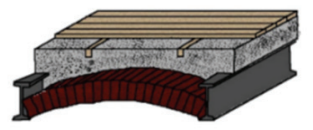

Fig. 1 - Floor structures used until the $19^{\text {th }}$ century: (a) Timber floor with joists without spacing; (b) Classic timber floor with timber joists with spacing; (c) Vaults between iron beams (redrawn from:[7])

In the $20^{\text {th }}$ century reinforced concrete began being used for floors more frequently. Later, many different floor types were invented, which especially lowered the material consumption and consequently diminished the floor weight (prefabricated concrete elements, masonry fillings, etc.). Afterward, the development of composite and prestressed systems followed. Parallel to the structural developments, building physics' demands have risen (sound insulation, thermal conductivity, etc.), which required floors consisting of multiple layers of materials with various properties.[7]

\section{TIMBER FLOOR TYPES}

In principle, there are two types of old timber floors. The first type is represented by timber floors without joist spacing (Fig. 1 a) and the second type by timber floors with joists with spacing (Fig. 1 b). A newer development is seen in the timber floor panels (Fig. 2 a), which have slender timber joists mechanically or adhesively connected to different wood-based sheeting boards. The latest type of timber floors consist of the cross-laminated timber floor elements (Fig. 2 b). Somewhat less often, glued laminated timber elements are also used for floors (Fig. 2 c). Instead of adhesives also mechanical connectors are used but to a much lesser extent. 
(a)

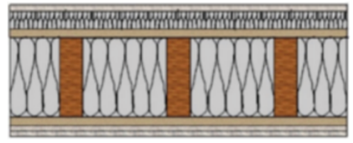

(c)

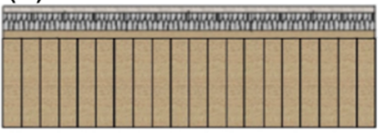

(b)

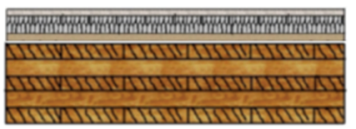

(d)

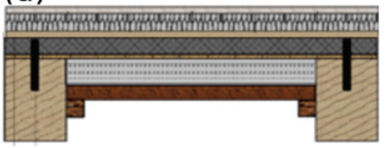

Fig. 2 - Timber floor types: (a) Timber floor panels; (b) Cross-laminated timber floor; (c) Glued laminated timber floor; (d) Timber-concrete composite floor

\subsection{Timber-Concrete Composite Floors}

The timber-concrete composite floor (Fig. 2 d) is a structural system, which is used for strengthening existing timber floors and for new construction projects. There are also examples of the system used in bridge construction [8]. The main advantages of the system are [7]:

- Rational use of various materials (concrete is in the compressive zone of the cross section and timber is in the tension zone of the cross section)

- Possibility of an undemanding strengthening of existing timber floors

- Relatively high bending stiffness

- Rigid diaphragm behavior

- Positive effect on the vibrational behavior of the floor

- Positive effect on the floor sound insulation properties

- Positive effect on the floor fire safety

The shear forces due to the composite action between timber and concrete are transmitted through mechanical connections. There are also attempts with adhesive layers providing the connection [9]. Different fasteners may be used for mechanical connections: bolts, nails, dowels, toothed plates. The concrete slab is usually reinforced in compliance with minimum reinforcement requiremeny, splitting forces resulting from mechanical connectors and rheological behavior of concrete (shrinkage) [7].

In addition, attention must also be given to the cultural heritage criteria, for example in Italy the timber-concrete approach for strengthening old timber floors was often rejected by responsible authorities due to claims that the measure is not reversible [6].

\subsection{Timber Floor Filling}

An important property of timber floors is the filling material inserted between timber joists. The filling material had the function of sound insulation, fire insulation and reduction of floor vibrations. According to [10] the materials used for timber floor fillings were: 
- construction waste (crushed masonry, usually burnt) with a density of about $1400 \mathrm{~kg} / \mathrm{m}^{3}$

- slag (without sulfur) with a density of about $850 \mathrm{~kg} / \mathrm{m}^{3}$

- black coal ash with a density of about $750 \mathrm{~kg} / \mathrm{m}^{3}$

- sand and gravel with a density of about $1400 \mathrm{~kg} / \mathrm{m}^{3}$

- clay with a density of about $1800 \mathrm{~kg} / \mathrm{m}^{3}$

Many variants of old timber floors with descriptions can be found in [11]. These descriptions were used to determine ratios of filling weight to floor weight. The results for each variant can be found in Table 1. The weight percentages reach from $20 \%$ to $65 \%$. The filling area weight in all variants is more than $0.5 \mathrm{kN} / \mathrm{m}^{2}$. Considering the low weight of new insulation materials, the removal of the filling may considerably influence the imposed load limit of the floor.

Table 1 - Floor weights and filling weight percentages (Figures redrawn from: [11])

\begin{tabular}{|c|c|c|c|c|c|}
\hline Timber floor variant & $\begin{array}{l}\text { Floor } \\
\text { area } \\
\text { weight }\end{array}$ & Filling & $\begin{array}{l}\text { Filling } \\
\text { volume per } \\
\text { area usage }\end{array}$ & $\begin{array}{l}\text { Filling } \\
\text { area } \\
\text { weight }\end{array}$ & $\begin{array}{c}\text { Weight } \\
\text { percentage of the } \\
\text { filling }\end{array}$ \\
\hline & {$\left[\frac{\mathrm{kN}}{\mathrm{m}^{2}}\right]$} & I & {$\left[\frac{m^{3}}{m^{2}}\right]$} & {$\left[\frac{\mathrm{kN}}{\mathrm{m}^{2}}\right]$} & {$[\%]$} \\
\hline & 2.24 & slug & 0.075 & 0.64 & 28.5 \\
\hline & 2.07 & sand & 0.040 & 0.56 & 27.1 \\
\hline & 2.20 & $\begin{array}{c}\text { construction } \\
\text { waste }\end{array}$ & 0.046 & 0.64 & 29.3 \\
\hline$=$ & 2.20 & sand & 0.062 & 0.87 & 39.5 \\
\hline & 2.88 & ash & 0.078 & 0.59 & 20.3 \\
\hline 垔 & 1.50 & slug & 0.079 & 0.67 & 44.8 \\
\hline 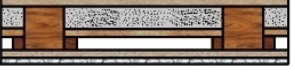 & 2.20 & clay & 0.079 & 1.42 & 64.6 \\
\hline
\end{tabular}




\subsubsection{Building Codes Related to Prescribed Imposed Loads}

In Slovenia (a former Yugoslav country), an increase of the prescribed imposed loads occured when the building standards in the former Yugoslavia have been changed and later when they were replaced with the Eurocodes, the current building standards in the European Union. The old Yugoslav building regulations from 1948, the PTP-2 ("Privremeni tehnicki propisi za opterecenje zgrada"), can be found in [12]. In 1988 the standard with prescribed imposed loads, the JUS U.C7.121, was introduced, which was identical with the standard ISO 2103:1986 [13]. After the entry of Slovenia into the European Union in 2004, the Eurocode 1 [14] had become the adopted standard for the prescribed imposed loads. Table 2 shows the prescribed imposed loads for residential areas, offices and exhibition halls from the mentioned standards. Comparing the differences between the minimum imposed loads with the floor filling weights, one can see that the increase of the minimum imposed loads (due to changing standards) can be partly alleviated or completely balanced out with the removal or replacement of the timber floor filling with a modern insulation material.

Table 2 - Prescribed minimum imposed loads from different standards

\begin{tabular}{|l|c|c|c|}
\hline & PTP-2 [12] & JUS U.C7.121 (ISO 2103:1986 [13] ) & Eurocode 1 [14] \\
\hline Area category & {$\left[\frac{\mathrm{kN}}{\mathrm{m}^{2}}\right]$} & {$\left[\frac{\mathrm{kN}}{\mathrm{m}^{2}}\right]$} & {$\left[\frac{\mathrm{kN}}{\mathrm{m}^{2}}\right]$} \\
\hline Residential areas & $1.25-1.5$ & 1.5 & 2.0 \\
\hline Offices & 2.0 & 2.0 & 3.0 \\
\hline Exhibition halls & 2.0 & 2.5 & 5.0 \\
\hline
\end{tabular}

\section{MEASURES FOR STRENGTHENING OLD TIMBER FLOORS}

Although old timber floors are often replaced with reinforced concrete floors, numerous measures can be used for strengthening. According to [11] some of these measures are:

- Decreasing the timber joist spacing

- Installation of additional beams under the floor for intermediate support

- Installation of additional joists under locations of concentrated loads

- Joist strengthening with nailed timber elements (Fig. 3 a)

- Forming of box girders by using the original joists, additional joists and sheeting boards (Fig. 3 b)

- Use of tension or bending elements connected to timber joists (Fig. 3 c). Materials such as steel or carbon fiber reinforced polymers are used.

- Use of tension elements and spacer posts, which enlarge the bending height of the crosssection (Fig. 3 d). It is also possible to pre-stress the timber joists with steel elements. 
- Forming of a composite cross-section (Fig. 2 d). Usually, concrete elements are added to the timber joists and mechanically connected with various steel fasteners.

Instead of concrete elements also cross-laminated timber elements are known to be used for forming composite cross sections [15].

(a)

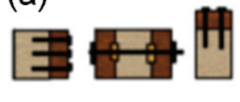

(c) (b)

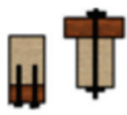

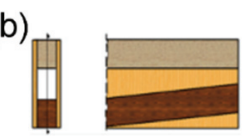

(d)

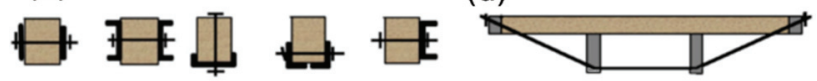

Fig. 3 - Timber floor strengthening methods: (a) Strengthening timber joists with nailed timber elements; (b) Forming of box girders; (c) Tension or bending elements connected to timber joists; (d) Enlarging the bending height with tension elements and spacer posts (redrawn from: [11])

There are also examples of forming a timber-concrete composite cross-section with an additional carbon fiber reinforced polymer strip in the tensile zone [16]. Bending tests (Fig. 4) for this measure can be found in [17].
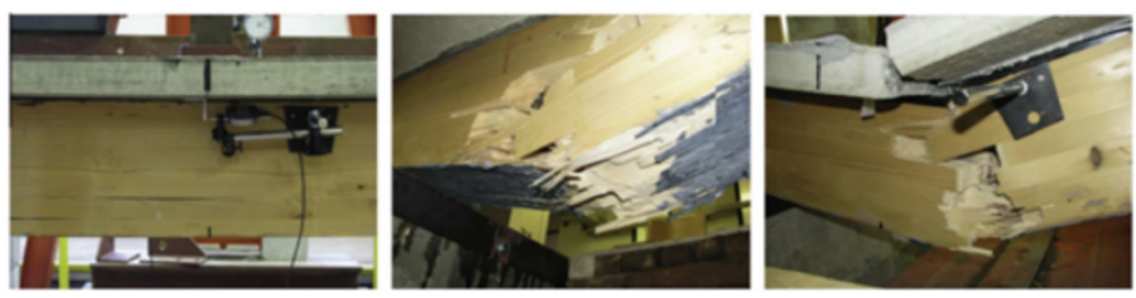

Fig. 4 - Bending tests of timber-concrete composite sections with additional carbon strips

Another option is the usage of steel collars which surround existing timber floor joists and is presented in [18]. The forces between the steel collars and the timber joists are transmitted through friction, which is ensured due to a rubber layer which is vulcanized, in contact with the steel collar and transversal ringing action due to bolt tightening. The collars are used to connect additional elements (for example concrete slabs) to the timber joists without perforating them and without causing any strength reduction.

\subsection{Timber Floor in-Plane Strengthening}

Besides the vertical behavior of floor structures, their horizontal behavior is also important, because the horizontal floor stiffness affects the stability or load-bearing capacity of the whole building. It is important to determine whether the floor structure can be considered a 
rigid diaphragm (Fig. 5) and if it can redistribute horizontal forces (wind or earthquake forces) to the neighboring elements - walls [19].
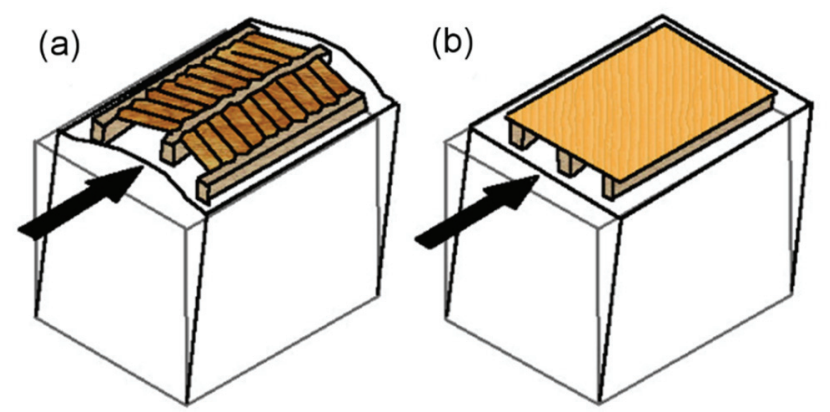

Fig. 5 - Role of the diaphragm preventing the overturning modes of masonry walls: (a) the inadequate in-plane stiffness of the floor causes overturning of the walls perpendicular to the seismic action; (b) a stiff diaphragm allows forces to be transmitted to the walls parallel to the seismic action (redrawn from:[20])

In cases where the timber floors do not behave as rigid diaphragms (or diaphragms at all), different wall collapse or overturning modes are possible (Fig. 6), as walls usually do not have sufficient strength for forces acting perpendicular to the wall plane [19].
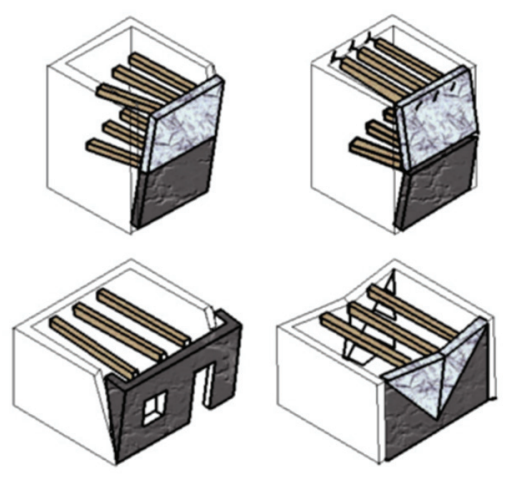

Fig. 6 - Wall overturning modes due to an inadequate stiffness of the floor (redrawn from:[20])

Although there are different ways of stiffening timber floors in the horizontal plane (Fig. 7), it turned out that some of these measures are only conditionally useful. Among them is the replacement of timber floors with reinforced concrete floors and installing reinforced concrete ties into the masonry, as the higher mass and higher stiffness can negatively impact 
the building [19]. The problem is the connection of the new reinforced concrete elements with the old masonry walls. As stated in [21], for a successful use of reinforced concrete elements it is necessary to ensure monolithic behavior of the old masonry walls, which are often built as a kind of layered structures, and to prevent the wall layers to separate, which is observed in seismic experiments and during actual earthquakes.

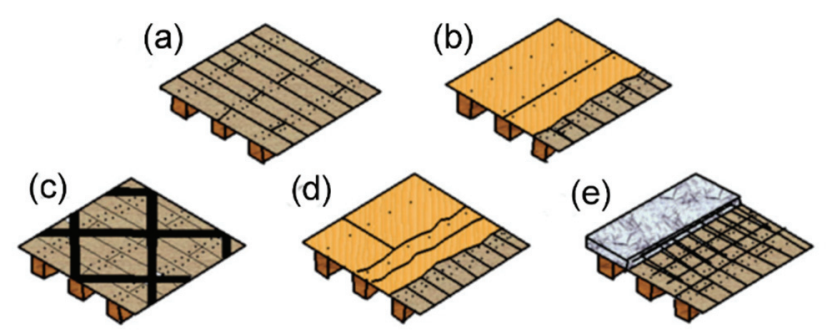

Fig. 7 - Different timber floor in-plane shear strengthening techniques: (a) existing simple layer of wood planks on the timber beams; (b) second layer of wood planks crossly arranged to the existing one and fixed by means of steel studs; (c) diagonal bracing of the existing wood planks by means of light steel plates or FRP laminae; (d) three layers of plywood panels glued on the existing wood planks; (e) a stud-connected reinforced concrete slab (redrawn from:[20])

In [20] installation of a steel curb and a reinforced concrete curb is shown as a measure of horizontal floor stiffening. Furthermore, $[22,23]$ discuss a timber floor on masonry walls, which were strengthened with prestressed steel ties on both sides and at the floor height, to act as a rigid diaphragm. In [24] the use of gang nails, which present a direct connection between the wooden boards, for horizontal stiffening of timber floors is investigated. In addition, [24] studied the use of carbon fiber-reinforced polymers strips for horizontal stiffening of timber floors. To sum up, there are many different timber floor strengthening techniques, but only a few of them simultaneously strengthen the timber floor "in-plane" and "out of plane" behavior. One of the few is the timber-concrete composite cross-section.

\section{NUMERICAL CASE STUDY OF A TIMBER FLOOR AND A TCC FLOOR}

Although timber floors can have random geometric properties, for example timber joist cross sections differing from a rectangular cross-section (Fig 8), Brezar [25] writes about the socalled 4-meter syndrome in European buildings, claiming that the most common span of European rooms is 4 meters, which is the consequence of different practical criteria such as easy transport or handleability. Brezar [25] also foresees that the dimension of a classic timber floor joist cross section should be $18 \mathrm{~cm}$ x $24 \mathrm{~cm}$. The same timber joist dimension can be found in [10], although for a $5 \mathrm{~m}$ span and a timber joist spacing of $0.9 \mathrm{~m}$. 


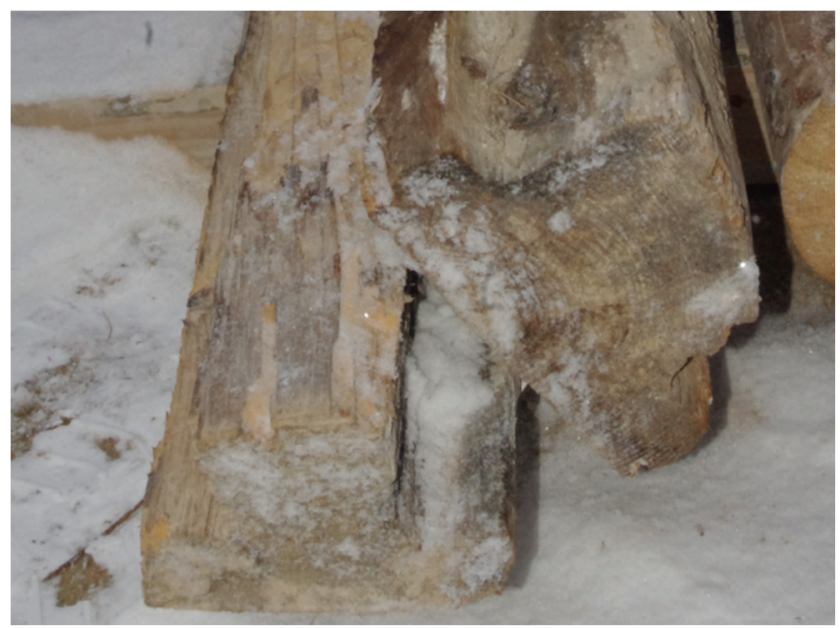

Fig. 8 - Timber joists with an inverted T-cross section from a demolished timber floor

To get an insight into the load-bearing capacity of old timber floors, the following numerical case study deals with the comparison of a classic timber floor for a $5 \mathrm{~m}$ span and a timberconcrete composite floor (TCC floor) with regards to their imposed load-bearing capacity. The TCC floor has the same timber joist dimension as the so-called classic timber floor. The numerical case study is conducted to provide an insight into the potential of classic timber floors and strengthening methods in view of complying with the current building standards.

\subsection{Timber Floor}

The floor section is given in Fig. 9 and the timber joist dimensions are given in Table 3. The wooden flooring is fitted on spacer boards, which were oriented perpendicularly to the timber joists and had an axial distance of about 1 meter. The space between the spacer boards and timber joists was filled with a mixture of sand and gravel. The function of the lower wooden boards was to hold the floor filling in place.

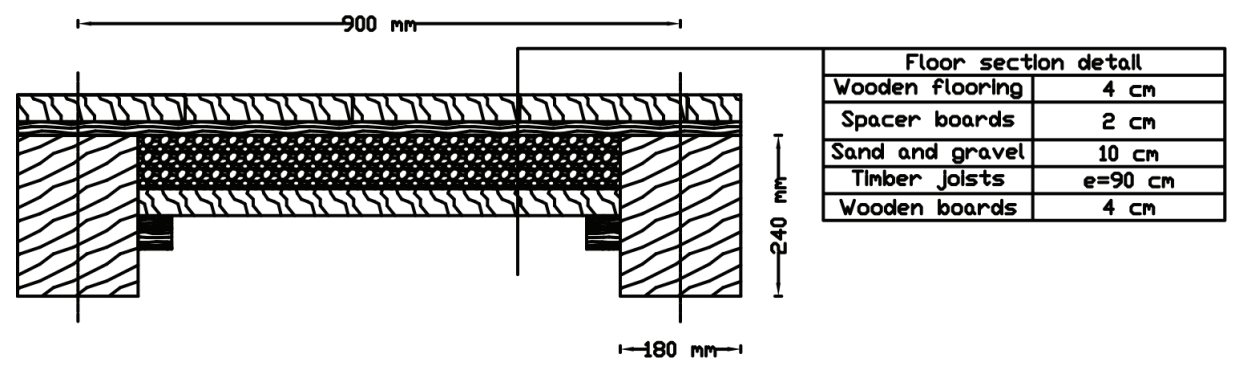

Fig. 9 - Floor section detail 
Table 3 - Geometric properties of the timber floor

\begin{tabular}{|l|c|c|c|}
\hline Timber joist width & $\mathrm{b}_{\mathrm{t}}$ & 18 & {$[\mathrm{~cm}]$} \\
\hline Timber joist height & $\mathrm{h}_{\mathrm{t}}$ & 24 & {$[\mathrm{~cm}]$} \\
\hline Span length & 1 & 5 & {$[\mathrm{~m}]$} \\
\hline Joist spacing & $\mathrm{e}$ & 90 & {$[\mathrm{~cm}]$} \\
\hline
\end{tabular}

\subsubsection{Mechanical Properties of the Timber Floor Joists}

The timber class of the timber joists was defined as C24 and the serviceability class as S2. The mechanical properties are given in Table 4.

Table 4 - Mechanical properties of timber class C24

\begin{tabular}{|l|l|l|l|}
\hline Characteristic bending strength & $\mathrm{f}_{\mathrm{m} . \mathrm{k}}$ & 24.00 & {$[\mathrm{MPa}]$} \\
\hline Characteristic tensile strength along the grain & $\mathrm{f}_{\mathrm{t} .0 . \mathrm{k}}$ & 14.00 & {$[\mathrm{MPa}]$} \\
\hline Characteristic shear strength & $\mathrm{f}_{\mathrm{v} . \mathrm{k}}$ & 2.50 & {$[\mathrm{MPa}]$} \\
\hline Mean value of modulus of elasticity & $\mathrm{E}_{\text {mean }}$ & 11.00 & {$[\mathrm{GPa}]$} \\
\hline Mean value of shear modulus & $\mathrm{G}_{\text {mean }}$ & 0.69 & {$[\mathrm{GPa}]$} \\
\hline Mean density & $\rho_{\mathrm{m}}$ & 420.00 & {$\left[\frac{\mathrm{kg}}{\mathrm{m}^{3}}\right]$} \\
\hline
\end{tabular}

\subsubsection{Structural Calculation}

To assess the load-bearing capacity of the given timber floor an analysis is performed according to Eurocode 5 [26]. The combination factors for area category C3 were used. The area category $\mathrm{C} 3$ in Eurocode 1 [14] has a prescribed imposed load of $5 \mathrm{kN} / \mathrm{m}^{2}$ and is defined as an area without obstacles for moving people. The input parameters for the structural calculation are given in Table 5 .

Although the actual span is 5 meters, calculations of maximum imposed loads (Q) are carried out for different spans, different ultimate and serviceability limit states criteria. Deflections from shear deformations are also considered. The final deflection is calculated taking timber creep into account. The static system is a simply supported beam. The design strengths are used for strength verifications $\left(X_{d}=k_{\bmod } \cdot \frac{X_{k}}{\gamma_{M}}\right)$. 
Table 5 - Input parameters for the structural calculation

\begin{tabular}{|c|c|c|c|}
\hline Floor self-weight & $\mathrm{G}$ & 1.55 & {$\left[\frac{\mathrm{kN}}{\mathrm{m}^{2}}\right]$} \\
\hline Filling density & $\rho_{\text {fill }}$ & 1300 & {$\left[\frac{\mathrm{kg}}{\mathrm{m}^{3}}\right]$} \\
\hline Partial factor for permanent actions & $\gamma_{\mathrm{G}}$ & 1.35 & $/$ \\
\hline Partial factor for variable actions & $\gamma_{\mathrm{Q}}$ & 1.50 & $/$ \\
\hline Modification factor for duration of load and moisture content & $\mathrm{k}_{\mathrm{mod}}$ & 0.80 & $/$ \\
\hline Crack factor for shear resistance & $\mathrm{k}_{\mathrm{cr}}$ & 0.67 & $/$ \\
\hline Factor for quasi-permanent value of a variable action & $\psi_{2}$ & 0.60 & $/$ \\
\hline Deformation factor & $\mathrm{k}_{\mathrm{def}}$ & 0.80 & $/$ \\
\hline Partial factor for material properties & $\gamma_{\mathrm{M}}$ & 1.30 & $/$ \\
\hline
\end{tabular}

Considered criteria in the calculation are:

- Ultimate limit state - Bending:

$$
\sigma_{\mathrm{m}, \mathrm{d}}=\frac{\mathrm{M}_{\mathrm{Ed}}}{\mathrm{I}_{\mathrm{t}, \mathrm{y}}} \cdot \frac{\mathrm{h}_{\mathrm{t}}}{2} \leq \mathrm{f}_{\mathrm{m}, \mathrm{d}}
$$

- Ultimate limit state - Shear

$$
\tau_{\mathrm{d}}=\frac{\mathrm{V}_{\mathrm{Ed}} \cdot \mathrm{S}_{\mathrm{y}}}{\mathrm{I}_{\mathrm{t}, \mathrm{y}} \cdot \mathrm{b}_{\mathrm{ef}}} \leq \mathrm{f}_{\mathrm{v}, \mathrm{d}}
$$

- Serviceability limit state - Instantaneous deflection (deflection limit: span/300)

$$
\mathrm{u}_{\mathrm{inst}}=\int_{0}^{1} \frac{\mathrm{M}_{\mathrm{Ed}, \mathrm{y} 0}(\mathrm{x}) \cdot \mathrm{M}_{\mathrm{Ed}, \mathrm{yl}}(\mathrm{x})}{\mathrm{E}_{\mathrm{t}} \cdot \mathrm{I}_{\mathrm{t}, \mathrm{y}}}+\int_{0}^{1} \frac{\mathrm{V}_{\mathrm{Ed}, \mathrm{z} 0}(\mathrm{x}) \cdot \mathrm{V}_{\mathrm{Ed}, \mathrm{zl}}(\mathrm{x})}{\mathrm{G}_{\mathrm{t}} \cdot \mathrm{A}_{\mathrm{t}, \mathrm{s}}} \leq \frac{1}{300}
$$

- Serviceability limit state - Final deflection (deflection limit: span/250)

$$
\mathrm{u}_{\mathrm{fin}} \cong \sum_{\mathrm{I}=1}^{\mathrm{N}} \mathrm{u}_{\mathrm{inst}, \mathrm{i}} \cdot\left(1+\psi_{2, \mathrm{i}} \cdot \mathrm{k}_{\mathrm{def}}\right) \leq \frac{1}{250}
$$

where $\sigma_{\mathrm{m}, \mathrm{d}}$ is the design bending stress, $\mathrm{M}_{\mathrm{Ed}}$ the design bending moment, $\mathrm{E}_{\mathrm{t}}$ the modulus of elasticity of timber, $I_{t, y}$ the timber joist cross section moment of inertia about the $y$-axis, $f_{m, d}$ the design bending strength, $\tau_{\mathrm{d}}$ the design shear stress, $\mathrm{V}_{\mathrm{Ed}}$ the design shear force, $\mathrm{S}_{\mathrm{y}}$ the first moment of area for the half of the timber joist cross-section, $b_{\mathrm{ef}}$ the effective width of the timber joist cross-section $\left(\mathrm{b}_{\mathrm{ef}}=\mathrm{b}_{\mathrm{t}} \cdot \mathrm{k}_{\mathrm{cr}}\right), \mathrm{f}_{\mathrm{v}, \mathrm{d}}$ the design shear strength, $\mathrm{u}_{\mathrm{inst}}$ the instantaneous 
deflection, $\mathrm{M}_{\mathrm{Ed}, \mathrm{y0}}(\mathrm{x})$ and $\mathrm{V}_{\mathrm{Ed}, \mathrm{z} 0}(\mathrm{x})$ the functions of the actual timber joist inner forces, $\mathrm{M}_{\mathrm{Ed}, \mathrm{yl}}(\mathrm{x})$ and $\mathrm{V}_{\mathrm{Ed}, \mathrm{zl}}(\mathrm{x})$ the functions of the timber joist inner forces due to virtual forces in the point and direction of the maximum deflections (middle span point and gravity direction), $G_{t}$ the shear modulus of timber, $A_{t, s}$ the effective shear area of the timber joist $\left(A_{t, s}=\frac{A_{t}}{1.2}\right.$ for rectangular cross-sections), $A_{t}$ the cross-section area of the timber joist, $u_{\text {fin }}$ the final deflection, $\mathrm{u}_{\text {inst, }}$ the instantaneous deflection for the individual load (permanent or variable).

The instantaneous deflection is calculated for the characteristic load combination, whereas the final deflection is calculated for the quasi-permanent load combination. The combination of actions for permenent or transient design situations is used for the ultimate limit state checks.

\subsubsection{Results}

The results for the calculation of maximum imposed loads for the classic timber floor are presented in Fig. 10.

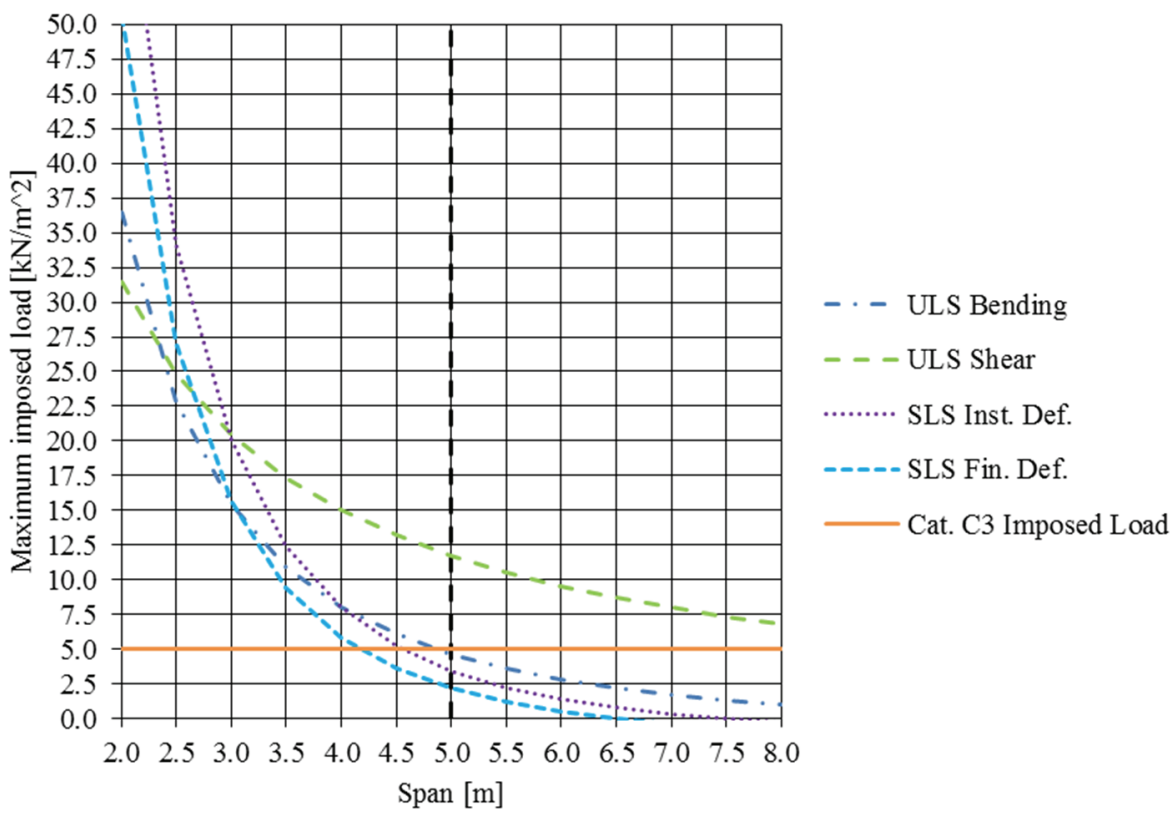

Fig. 10 - The dependence of maximum allowable imposed load on the span length-timber floor (the vertical dashed line labels the actual floor span)

Fig. 10 shows that the final deflection is the most critical criterion. The maximum allowable imposed load for our timber floor is about $2.5 \mathrm{kN} / \mathrm{m}^{2}$ as allowed by the serviceability criteria. Considering our chosen area category (C3), the maximum calculated allowable imposed load from the serviceability criteria is too low, the ULS criteria, on the other hand, are met. Moreover, the shear strength seems to be the most uncritical criterion. If the floor is used for 
category A (floors), both the ULS and SLS criteria will be met, as the characteristic value for category A the imposed load is $2.0 \mathrm{kN} / \mathrm{m}^{2}$ However, considering the high floor filling weight of about $1.0 \mathrm{kN} / \mathrm{m}^{2}$, a replacement of the filling material with a modern and light insulation material will result in considerably higher allowable (maximum) imposed loads. To conclude, it can be also seen that the SLS criteria are the most critical for spans longer than $3.0 \mathrm{~m}$, for spans shorter than $3.0 \mathrm{~m}$ the ULS criteria are more critical.

\subsection{Timber-Concrete Composite Floor}

As previously presented, the timber floor does not meet the ULS and SLS criteria for area category C3. Our next analysis includes a contribution of the concrete slab to the load-bearing capacity in a composite floor element with the same timber joist properties as in the investigated timber floor (5.1. Timber Floor). The timber-concrete composite floor section (with all details) is given in Fig. 11 and, in comparison to the timber floor section, presents a modern floor which should also comply with today's housing culture. The concrete slab segment geometric properties are given in Table 6 . The mechanical connectors between the concrete slab and timber joists were steel dowels.

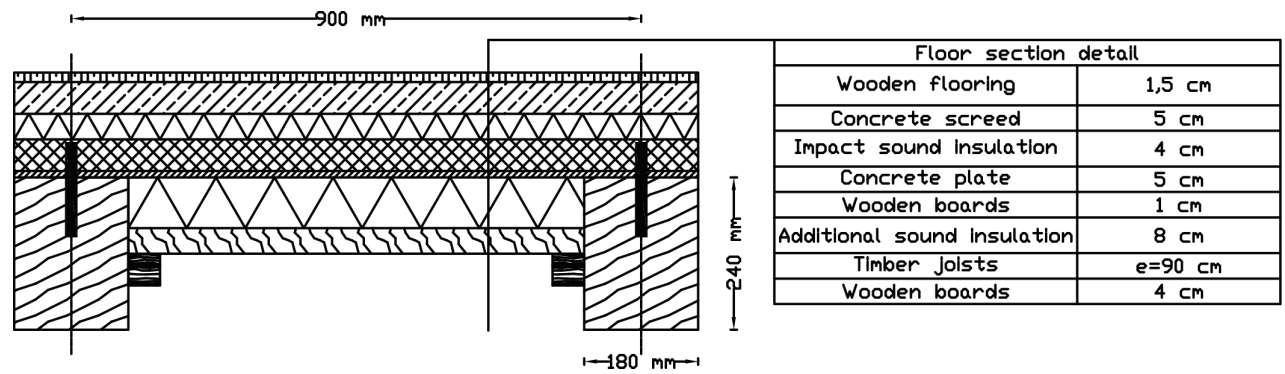

Fig. 11 - Timber-concrete composite section detail

Table 6 - Geometric properties of the concrete slab (segment)

\begin{tabular}{|l|c|c|c|}
\hline Concrete slab segment width & $\mathrm{b}_{\mathrm{c}}(=\mathrm{e})$ & 90 & {$[\mathrm{~cm}]$} \\
\hline Concrete slab thickness & $\mathrm{h}_{\mathrm{c}}$ & 5 & {$[\mathrm{~cm}]$} \\
\hline Uncracked concrete slab thickness (initial value for all limit states) & $\mathrm{x}_{\mathrm{c}}$ & 5 & {$[\mathrm{~cm}]$} \\
\hline $\begin{array}{l}\text { Thickness of wooden boards between the timber joist and concrete } \\
\text { slab (for considering the gap between the timber joists and concrete } \\
\text { slab) }\end{array}$ & $\mathrm{t}_{\mathrm{wb}}$ & 1 & {$[\mathrm{~cm}]$} \\
\hline
\end{tabular}




\subsubsection{Mechanical Properties of the Concrete Slab}

The strength class of the concrete slab is defined as C20. The mechanical properties are given in Table 7.

Table 7 - Mechanical properties of concrete class C20

\begin{tabular}{|l|c|c|c|}
\hline Characteristic compressive cylinder strength of concrete at 28 days & $f_{\mathrm{ck}}$ & 20 & {$[\mathrm{MPa}]$} \\
\hline Secant modulus of elasticity & $\mathrm{E}_{\mathrm{cm}}$ & 30 & {$[\mathrm{GPa}]$} \\
\hline Mean density & $\rho_{\mathrm{c}, \mathrm{m}}$ & 2500 & {$\left[\frac{\mathrm{kg}}{\mathrm{m}^{3}}\right]$} \\
\hline
\end{tabular}

\subsubsection{Structural Calculation}

The calculations are performed in compliance with the so-called "gamma method" from Annex B of Eurocode 5 [26]. The input parameters for the structural calculation are given in Table 8.

The connectors are only used for stiffness requirements and are not structurally checked. During construction, the floor should be fully supported consequently, the floor self-weight and imposed loads are defined as completely resisted by the composite section. The concrete tensile strength is considered to be zero; therefore concrete is understood as to fail under tension. Although minimum reinforcement should be present in the concrete slab, this is not taken into consideration in structural calculation. The uncracked concrete slab thickness is calculated iteratively (if the first step of the calculation shows tensile stresses in the concrete slab). The new thickness or uncracked section thickness, $x_{c}$, is used to recalculate the floor bending stiffness of each iteration step, although $\gamma$, the coefficient of composite action, is calculated only for the uncracked concrete thickness. The reason for this is the reflection of the global composite beam behavior through the $\gamma$ coefficient. The static system is a simply supported beam.

Table 8 - Input parameters for the structural calculation

\begin{tabular}{|l|c|c|c|}
\hline Floor self-weight & $\mathrm{G}$ & 2.8 & {$\left[\frac{\mathrm{kN}}{\mathrm{m}^{2}}\right]$} \\
\hline Concrete creep coefficient & $\phi_{\mathrm{c}}$ & 3.0 & $/$ \\
\hline Dowel diameter & $\mathrm{d}_{\mathrm{dow}}$ & 20 & {$[\mathrm{~mm}]$} \\
\hline Dowel spacing & $\mathrm{s}_{\mathrm{dow}}$ & 10 & {$[\mathrm{~cm}]$} \\
\hline Modification factor for duration of load and moisture content & $\mathrm{k}_{\mathrm{mod}}$ & 0.8 & $/$ \\
\hline Partial factor for concrete for ultimate limit states & $\gamma_{\mathrm{C}}$ & 1.5 & $/$ \\
\hline
\end{tabular}


Creep of both materials (timber and concrete) is considered in the calculation. The ULS criteria depend only on timber tensile and bending strength, as the concrete compressive strength $\left(\frac{\mathrm{f}_{\mathrm{ck}}}{\gamma_{\mathrm{c}}}=13.3 \mathrm{MPa}\right)$ is never exceeded. Although the actual span is 5 meters, calculations of maximum imposed loads (Q) for different spans, different ultimate and serviceability limit states criteria are carried out. Deflections from shear deformations are not considered. The whole concrete slab width is considered for calculation, as the determination of the effective flange width (according to Eurocode 2 [27]), $b_{\text {eff }}$, shows that the calculated effective flange width is greater than the actual concrete slab segment width, $b_{c}$, for spans longer than approximately $3.4 \mathrm{~m}$. The results for spans shorter than $3.4 \mathrm{~m}$ are therefore slightly overestimated.

The effective bending stiffness $\left((\mathrm{EI})_{\mathrm{ef}}\right)$ of the composite floor is defined with:

$(\mathrm{EI})_{\mathrm{ef}}=\sum_{\mathrm{I}=1}^{\mathrm{N}}\left(\mathrm{E}_{\mathrm{i}} \cdot \mathrm{I}_{\mathrm{i}}+\gamma_{\mathrm{i}} \cdot \mathrm{E}_{\mathrm{i}} \cdot \mathrm{A}_{\mathrm{i}} \cdot \mathrm{a}_{\mathrm{i}}^{2}\right)$

where $E_{i}$ is the modulus of elasticity of the individual material, $A_{i}$ the (uncracked) crosssection area of the individual member, $a_{t}$ the distance between the centers of gravity of the individual cross-section and composite cross-section and $\mathrm{I}_{\mathrm{i}}$ the moment of inertia of the individual cross section.

The $\gamma$ coefficient for timber is equal to 1.0, the $\gamma$ coefficient for the concrete slab (for the appropriate limit state) is defined with:

$\gamma=\frac{1}{1+\frac{\left(\pi^{2} \cdot \mathrm{E}_{\mathrm{c}} \cdot \mathrm{h}_{\mathrm{c}} \cdot \mathrm{b}_{\mathrm{c}} \cdot \mathrm{s} \text { dow }\right.}{\mathrm{K}_{\mathrm{i}} \cdot \mathrm{l}^{2}}}$

where $\mathrm{K}_{\mathrm{i}}$ is the slip modulus for the considered limit state. The instantaneous slip modulus for serviceability limit states is defined with:

$\mathrm{K}_{\mathrm{ser}}=\frac{2 \cdot\left(\frac{\rho_{\mathrm{m}}}{\frac{\mathrm{kg}}{\mathrm{m}^{3}}}\right)^{1.5} \frac{\mathrm{d}_{\mathrm{dow}}}{\mathrm{mm}}}{23} \cdot \frac{\mathrm{N}}{\mathrm{mm}}$

The instantaneous slip modulus for ultimate limit states is defined with:

$\mathrm{K}_{\mathrm{u}}=\frac{2}{3} \cdot \mathrm{K}_{\mathrm{ser}}$

The final slip modulus for ultimate limit states is defined with:

$\mathrm{K}_{\mathrm{u}, \mathrm{fin}}=\frac{\mathrm{K}_{\mathrm{u}}}{1+\frac{\left(\mathrm{k}_{\mathrm{def}} \psi_{2}+\phi_{\mathrm{c}}\right)}{2}}$

The final slip modulus for serviceability limit states is defined with: 
$\mathrm{K}_{\mathrm{ser}, \mathrm{fin}}=\frac{\mathrm{K}_{\mathrm{ser}}}{1+\frac{\left(\mathrm{kdef}_{\mathrm{def}} \phi_{\mathrm{c}}\right)}{2}}$

For the instantaneous design checks the mean values of moduli of elasticity $\left(\mathrm{E}_{\mathrm{c}}=\mathrm{E}_{\mathrm{cm}}\right.$ and $\mathrm{E}_{\mathrm{t}}=\mathrm{E}_{\text {mean }}$ ) are used, whereas modified values are used for the final design checks (due to creep).

The timber final modulus of elasticity for ultimate limit states is defined with:

$E_{t, u}=\frac{E_{\text {mean }}}{1+k_{\text {der }} \psi_{2}}$

The timber final modulus of elasticity for serviceability limit states is defined with:

$E_{t, \text { ser }}=\frac{E_{\text {mean }}}{1+k_{\text {def }}}$

The concrete final modulus of elasticity for the ultimate and serviceability limit states is defined with:

$E_{c}=\frac{E_{c m}}{1+\phi_{c}}$

The axial force (due to composite action) stress component of the individual cross section is defined with:

$\sigma_{\mathrm{N}, \mathrm{i}}=\frac{\gamma_{\mathrm{i}} \cdot \mathrm{E}_{\mathrm{i}} \cdot \mathrm{a}_{\mathrm{i}} \cdot \mathrm{M}_{\mathrm{Ed}}}{(\mathrm{EI})_{\mathrm{ef}}}$

The bending moment stress component of the individual cross section is defined with:

$\sigma_{\mathrm{M}, \mathrm{i}}=\frac{0.5 \cdot \mathrm{E}_{\mathrm{i}} \cdot \mathrm{h}_{\mathrm{i}} \cdot \mathrm{M}_{\mathrm{Ed}}}{(\mathrm{EI})_{\mathrm{ef}}}$

where $h_{i}$ is the uncracked height (in case of the concrete slab $x_{c}$ ).

The total normal stress of the individual cross section is defined with:

$\sigma_{\mathrm{i}}=\sigma_{\mathrm{N}, \mathrm{i}}+\sigma_{\mathrm{M}, \mathrm{i}}$

In the calculation considered criteria are:

- Serviceability limit state - Instantaneous deflection (deflection limit: span/300)

The characteristic load combination is used for checking instantaneous deflection.

$\mathrm{u}_{\mathrm{inst}}=\int_{0}^{1} \frac{\mathrm{M}_{\mathrm{Ed}, \mathrm{y} 0}(\mathrm{x}) \cdot \mathrm{M}_{\mathrm{Ed}, \mathrm{yl}}(\mathrm{x})}{(\mathrm{EI})_{\mathrm{ef}}} \leq \frac{1}{300}$

- Serviceability limit state - Final deflection (deflection limit: span/250) 
The quasi-permanent load combination is used for checking the final deflection. This limit state considers creep of both materials (timber and concrete).

$\mathrm{u}_{\mathrm{fin}}=\int_{0}^{1} \frac{\mathrm{M}_{\mathrm{Ed}, \mathrm{y} 0}(\mathrm{x}) \cdot \mathrm{M}_{\mathrm{Ed}, \mathrm{yl}}(\mathrm{x})}{(\mathrm{EI})_{\mathrm{ef}}} \leq \frac{1}{250}$

- Ultimate limit state - Bending Instantaneous

$\frac{\sigma_{\mathrm{N}, \mathrm{t}}}{\mathrm{f}_{\mathrm{t}, 0, \mathrm{~d}}}+\frac{\sigma_{\mathrm{M}, \mathrm{t}}}{\mathrm{f}_{\mathrm{m}, \mathrm{d}}} \leq 1$

- $\quad$ Ultimate limit state - Bending Final

This limit state considers creep of both materials (timber and concrete). The equation (19) is applied with appropriate input parameters.

- Ultimate limit state - Shear

Only the shear capacity of the timber joists is used, which means that the results for the maximum imposed load from the ULS - Shear criterion are conservative. The equation (2) is applied.

\subsubsection{Results}

The results for the calculation of maximum imposed loads for the timber-concrete composite floor are given in Fig. 12.

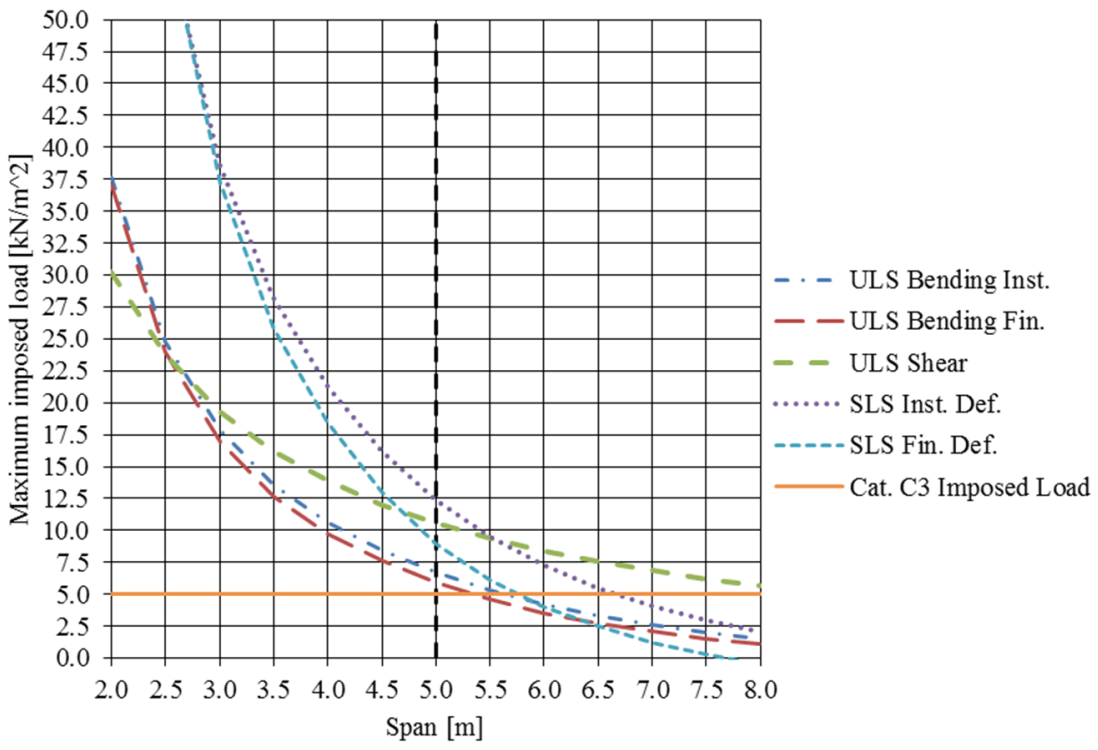

Fig. 12 - Dependence of the maximum allowable imposed load on the span length-timberconcrete composite floor (the vertical dashed line labels the actual floor span) 
It can be seen from Fig. 12 that the most critical criterion for the composite floor of $5 \mathrm{~m}$ span is the ULS Bending criteria. The maximum allowable imposed load regarding the SLS - Fin. Def. criterion for the timber-concrete composite floor is about $9.0 \mathrm{kN} / \mathrm{m}^{2}$, whereas for the ULS - Bending Final criterion the maximum allowable imposed load is about $5.9 \mathrm{kN} / \mathrm{m}^{2}$.

The ULS - Bending criteria are the decisive criteria for spans shorter than $6.5 \mathrm{~m}$, for longer spans the SLS Fin. Def. maximum imposed load is the decisive criterion. The ULS - Shear criterion is mostly uncritical, even after the shear load is (computationally) completely resisted by the timber joists.

According to our chosen category of use and span length, the calculated maximum allowable imposed loads from the serviceability and ultimate criteria are high enough for the category C3.

Detailed results for each criterion and span length ( $\sigma_{\text {c.top }}$ is the concrete slab top stress and $\sigma_{\mathrm{c}, \text { bot }}$ is the uncracked concrete slab bottom stress):

- Ultimate limit state - Bending Instantaneous (results are given in Table 9)

Table 9 - Results for »Ultimate limit state - Bending Instantaneous»

\begin{tabular}{|c|c|c|c|c|c|c|c|}
\hline 1 & $\mathrm{Q}$ & $\sigma_{\mathrm{c} . t o p}$ & $\sigma_{\mathrm{c}, \text { bot }}$ & $\mathrm{x}_{\mathrm{c}}$ & $(\mathrm{EI})_{\mathrm{ef}}$ & $\mathrm{K}$ & $\gamma$ \\
\hline$[\mathrm{m}]$ & {$\left[\frac{\mathrm{kN}}{\mathrm{m}^{2}}\right]$} & {$[\mathrm{MPa}]$} & {$[\mathrm{MPa}]$} & {$[\mathrm{cm}]$} & {$\left[\mathrm{GN} \cdot \mathrm{cm}^{2}\right]$} & {$\left[\frac{\mathrm{kN}}{\mathrm{cm}}\right]$} & $/$ \\
\hline 2.0 & 37.60 & -3.23 & 0.00 & 1.00 & 25.20 & 99.80 & 0.03 \\
\hline 2.5 & 24.75 & -4.58 & 0.00 & 1.49 & 28.04 & 99.80 & 0.04 \\
\hline 3.0 & 17.85 & -5.78 & 0.00 & 2.00 & 32.20 & 99.80 & 0.06 \\
\hline 3.5 & 13.59 & -6.71 & 0.00 & 2.51 & 37.44 & 99.80 & 0.08 \\
\hline 4.0 & 10.63 & -7.36 & 0.00 & 2.99 & 43.32 & 99.80 & 0.11 \\
\hline 4.5 & 8.43 & -7.78 & 0.00 & 3.42 & 49.39 & 99.80 & 0.13 \\
\hline 5.0 & 6.72 & -8.04 & 0.00 & 3.79 & 55.29 & 99.80 & 0.16 \\
\hline 5.5 & 5.36 & -8.19 & 0.00 & 4.11 & 60.80 & 99.80 & 0.18 \\
\hline 6.0 & 4.26 & -8.27 & 0.00 & 4.39 & 65.81 & 99.80 & 0.21 \\
\hline 6.5 & 3.36 & -8.31 & 0.00 & 4.62 & 70.30 & 99.80 & 0.24 \\
\hline 7.0 & 2.63 & -8.33 & 0.00 & 4.82 & 74.28 & 99.80 & 0.27 \\
\hline 7.5 & 2.01 & -8.33 & 0.00 & 4.99 & 77.78 & 99.80 & 0.30 \\
\hline 8.0 & 1.49 & -8.33 & -0.19 & 5.00 & 80.34 & 99.80 & 0.32 \\
\hline
\end{tabular}


- $\quad$ Ultimate limit state - Bending Final (results are given in Table 10)

Table 10 - Results for »Ultimate limit state - Bending Final«

\begin{tabular}{|c|c|c|c|c|c|c|c|}
\hline 1 & $\mathrm{Q}$ & $\sigma_{\mathrm{c} . t o p}$ & $\sigma_{\mathrm{c}, \text { bot }}$ & $\mathrm{x}_{\mathrm{c}}$ & $(\mathrm{EI})_{\mathrm{ef}}$ & $\mathrm{K}$ & $\gamma$ \\
\hline$[\mathrm{m}]$ & {$\left[\frac{\mathrm{kN}}{\mathrm{m}^{2}}\right]$} & {$[\mathrm{MPa}]$} & {$[\mathrm{MPa}]$} & {$[\mathrm{cm}]$} & {$\left[\mathrm{GN} \cdot \mathrm{cm}^{2}\right]$} & {$\left[\frac{\mathrm{kN}}{\mathrm{cm}}\right]$} & $/$ \\
\hline 2.0 & 37.02 & -1.72 & 0.00 & 1.43 & 16.62 & 36.42 & 0.04 \\
\hline 2.5 & 23.96 & -2.45 & 0.00 & 2.11 & 18.01 & 36.42 & 0.06 \\
\hline 3.0 & 16.93 & -3.13 & 0.00 & 2.82 & 20.00 & 36.42 & 0.09 \\
\hline 3.5 & 12.63 & -3.69 & 0.00 & 3.53 & 22.48 & 36.42 & 0.12 \\
\hline 4.0 & 9.71 & -4.12 & 0.00 & 4.19 & 25.24 & 36.42 & 0.15 \\
\hline 4.5 & 7.59 & -4.42 & 0.00 & 4.79 & 28.09 & 36.42 & 0.18 \\
\hline 5.0 & 5.91 & -4.60 & -0.19 & 5.00 & 30.32 & 36.42 & 0.21 \\
\hline 5.5 & 4.59 & -4.73 & -0.47 & 5.00 & 32.09 & 36.42 & 0.25 \\
\hline 6.0 & 3.57 & -4.84 & -0.72 & 5.00 & 33.77 & 36.42 & 0.28 \\
\hline 6.5 & 2.75 & -4.94 & -0.94 & 5.00 & 35.35 & 36.42 & 0.32 \\
\hline 7.0 & 2.08 & -5.03 & -1.13 & 5.00 & 36.81 & 36.42 & 0.35 \\
\hline 7.5 & 1.53 & -5.11 & -1.30 & 5.00 & 38.17 & 36.42 & 0.38 \\
\hline 8.0 & 1.08 & -5.18 & -1.45 & 5.00 & 39.41 & 36.42 & 0.41 \\
\hline
\end{tabular}

- $\quad$ Ultimate limit state - Shear (results are given in Table 11)

Table 11 - Results for »Ultimate limit state - Shear»

\begin{tabular}{|c|c|c|c|c|c|c|c|c|c|c|c|c|c|c|}
\hline 1 & {$[\mathrm{~m}]$} & 2.0 & 2.5 & 3.0 & 3.5 & 4.0 & 4.5 & 5.0 & 5.5 & 6.0 & 6.5 & 7.0 & 7.5 & 8.0 \\
\hline $\mathrm{Q}$ & {$\left[\frac{\mathrm{kN}}{\mathrm{m}^{2}}\right]$} & 30.28 & 23.71 & 19.34 & 16.21 & 13.87 & 12.04 & 10.58 & 9.39 & 8.40 & 7.56 & 6.83 & 6.21 & 5.66 \\
\hline
\end{tabular}

- Serviceability limit state - Instantaneous deflection (deflection limit: span/300) (results are given in Table 12) 
Table 12 - Results for »Serviceability limit state - Instantaneous deflection«

\begin{tabular}{|c|c|c|c|c|c|c|c|}
\hline 1 & $\mathrm{Q}$ & $\sigma_{\mathrm{c} . t o p}$ & $\sigma_{\mathrm{c}, \mathrm{bot}}$ & $\mathrm{x}_{\mathrm{c}}$ & $(\mathrm{EI})_{\mathrm{ef}}$ & $\mathrm{K}$ & $\gamma$ \\
\hline$[\mathrm{m}]$ & {$\left[\frac{\mathrm{kN}}{\mathrm{m}^{2}}\right]$} & {$[\mathrm{MPa}]$} & {$[\mathrm{MPa}]$} & {$[\mathrm{cm}]$} & {$\left[\mathrm{GN} \cdot \mathrm{cm}^{2}\right]$} & {$\left[\frac{\mathrm{kN}}{\mathrm{cm}}\right]$} & $/$ \\
\hline 2.0 & 95.62 & -6.89 & 0.00 & 1.44 & 27.69 & 149.69 & 0.04 \\
\hline 2.5 & 56.88 & -7.94 & 0.00 & 2.07 & 32.80 & 149.69 & 0.07 \\
\hline 3.0 & 38.72 & -8.59 & 0.00 & 2.68 & 39.44 & 149.69 & 0.09 \\
\hline 3.5 & 28.22 & -8.89 & 0.00 & 3.24 & 46.80 & 149.69 & 0.12 \\
\hline 4.0 & 21.23 & -8.93 & 0.00 & 3.72 & 54.12 & 149.69 & 0.15 \\
\hline 4.5 & 16.19 & -8.79 & 0.00 & 4.12 & 60.92 & 149.69 & 0.19 \\
\hline 5.0 & 12.41 & -8.54 & 0.00 & 4.45 & 66.97 & 149.69 & 0.22 \\
\hline 5.5 & 9.52 & -8.24 & 0.00 & 4.72 & 72.24 & 149.69 & 0.25 \\
\hline 6.0 & 7.28 & -7.91 & 0.00 & 4.94 & 76.77 & 149.69 & 0.29 \\
\hline 6.5 & 5.48 & -7.54 & -0.16 & 5.00 & 80.15 & 149.69 & 0.32 \\
\hline 7.0 & 4.05 & -7.19 & -0.33 & 5.00 & 82.95 & 149.69 & 0.36 \\
\hline 7.5 & 2.93 & -6.86 & -0.46 & 5.00 & 85.43 & 149.69 & 0.39 \\
\hline 8.0 & 2.04 & -6.56 & -0.56 & 5.00 & 87.62 & 149.69 & 0.42 \\
\hline
\end{tabular}

The results for bending and deflection limits states (Table 9, Table 10, Table 12 and Table 13) show that creep has a negative impact on the load-bearing capacity and it also affects the distribution of stresses. Although the concrete slab compressive stresses are averagely higher before creep, the concrete slab is more likely to be uncracked after creep (for longer spans). It is also noticed that the coefficient of composite behavior, $\gamma$, is higher after creep. A deeper look into this fact reveals that timber creep decreases the $\gamma$ coefficient, concrete creep, on the other hand, increases the $\gamma$ coefficient. As the chosen value for the concrete creep coefficient, $\phi_{c}$, was higher than the timber creep $\left(k_{\text {def }}\right)$ for serviceability limit state or $k_{\text {def }} \cdot \psi_{2}$ for the ultimate limit state), this results in a higher $\gamma$ coefficient. Moreover, if the creep values for concrete and timber are equal, the creep will have no effect on the $\gamma$ coefficient. Furthermore, observations reveal that the maximum imposed loads for the serviceability limit state after creep (Table 13) for spans shorter than $3 \mathrm{~m}$ are higher than the maximum imposed loads for the serviceability limit state before creep (Table 12). This is also a consequence of the $\gamma$ coefficients being higher after creep and of the fact that the percentage difference between the $\gamma$ coefficients (between the before and after creep values) is higher for shorter spans. 
The concrete stresses are for all limit states considerably lower than the design concrete compressive strength $\left(\frac{f_{\mathrm{ck}}}{\gamma_{\mathrm{c}}}=13.3 \mathrm{MPa}\right)$, which insinuates that using a higher concrete strength class would not give better results (higher maximum imposed loads) considering the rather small differences in the moduli of elasticity for different concrete strength classes.

- Serviceability limit state - Final deflection (deflection limit: span/250) (results are given in Table 13)

Table 13 - Results for »Serviceability limit state - Final deflection»

\begin{tabular}{|c|c|c|c|c|c|c|c|}
\hline 1 & $\mathrm{Q}$ & $\sigma_{\text {c.top }}$ & $\sigma_{\mathrm{c}, \text { bot }}$ & $\mathrm{x}_{\mathrm{c}}$ & $(\mathrm{EI})_{\mathrm{ef}}$ & $\mathrm{K}$ & $\gamma$ \\
\hline$[\mathrm{m}]$ & {$\left[\frac{\mathrm{kN}}{\mathrm{m}^{2}}\right]$} & {$[\mathrm{MPa}]$} & {$[\mathrm{MPa}]$} & {$[\mathrm{cm}]$} & {$\left[\mathrm{GN} \cdot \mathrm{cm}^{2}\right]$} & {$\left[\frac{\mathrm{kN}}{\mathrm{cm}}\right]$} & $/$ \\
\hline 2.0 & 100.96 & -2.78 & 0.00 & 1.93 & 14.86 & 51.62 & 0.06 \\
\hline 2.5 & 57.44 & -3.18 & 0.00 & 2.76 & 17.07 & 51.62 & 0.09 \\
\hline 3.0 & 37.23 & -3.43 & 0.00 & 3.57 & 19.90 & 51.62 & 0.12 \\
\hline 3.5 & 25.83 & -3.54 & 0.00 & 4.30 & 23.02 & 51.62 & 0.16 \\
\hline 4.0 & 18.50 & -3.55 & 0.00 & 4.93 & 26.11 & 51.62 & 0.20 \\
\hline 4.5 & 12.90 & -3.42 & -0.22 & 5.00 & 28.21 & 51.62 & 0.24 \\
\hline 5.0 & 8.97 & -3.28 & -0.40 & 5.00 & 30.06 & 51.62 & 0.28 \\
\hline 5.5 & 6.15 & -3.15 & -0.53 & 5.00 & 31.75 & 51.62 & 0.32 \\
\hline 6.0 & 4.06 & -3.03 & -0.63 & 5.00 & 33.29 & 51.62 & 0.36 \\
\hline 6.5 & 2.47 & -2.91 & -0.70 & 5.00 & 34.68 & 51.62 & 0.40 \\
\hline 7.0 & 1.25 & -2.80 & -0.75 & 5.00 & 35.93 & 51.62 & 0.43 \\
\hline 7.5 & 0.28 & -2.70 & -0.78 & 5.00 & 37.05 & 51.62 & 0.47 \\
\hline 8.0 & -0.48 & -2.60 & -0.80 & 5.00 & 38.05 & 51.62 & 0.50 \\
\hline
\end{tabular}

\subsubsection{Impact of Concrete Slab Thickness on the Maximum Imposed Load}

In addition to the span length, the concrete slab thickness is also varied. The results for the maximum imposed load regarding the »Ultimate limit state - Bending Final« criterion can be seen in Fig. 13. The criterion is chosen because it is the most critical criterion in the previously presented example. 


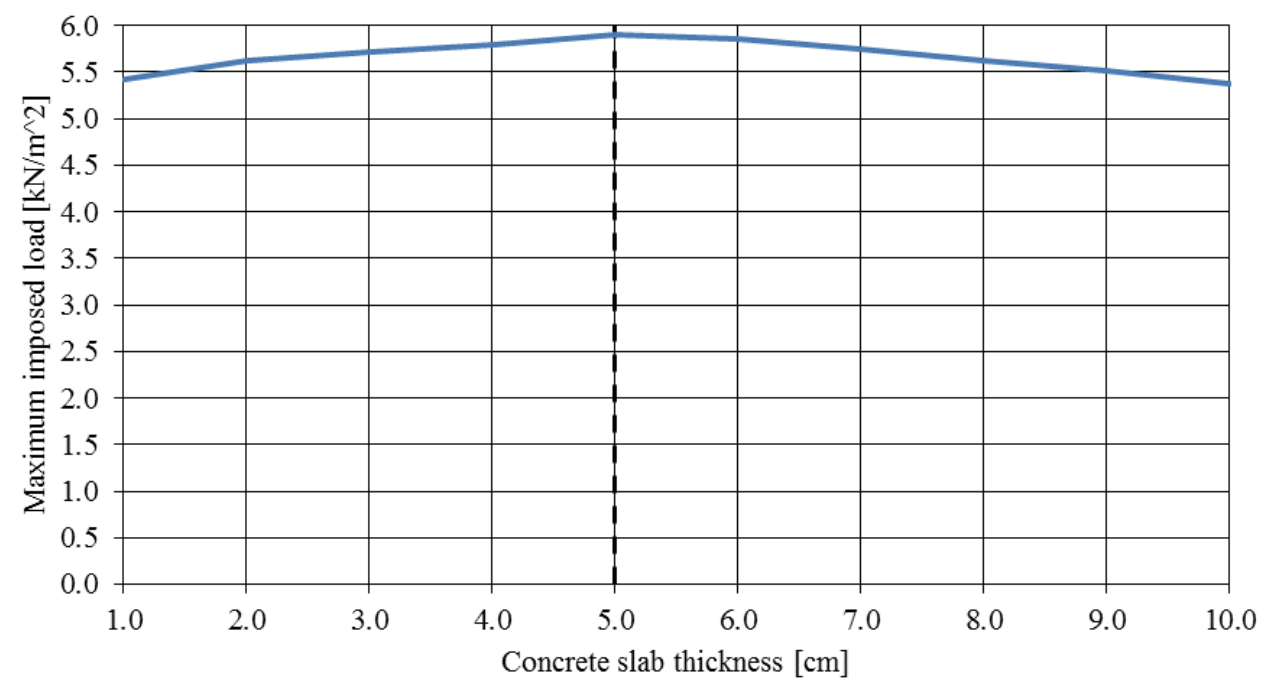

Fig. 13 - Dependence of the timber-concrete composite floor maximum allowable imposed load on the concrete slab thickness - „Ultimate limit state - Bending Final criterion (the dashed line labels the chosen concrete slab thickness)

The results clearly show that increasing the concrete slab thickness does not result in a higher load-bearing capacity (maximum imposed load) of the TCC floor. The load-bearing capacity of the composite floor is limited by the timber strength, as the concrete compressive strength $\left(\frac{f_{c k}}{\gamma_{c}}=13.3 \mathrm{MPa}\right)$ is not even nearly exceeded. This is a consequence of the concrete slab only strengthening the compressive zone of the composite section. Detailed results can be extracted from Table 14.

Table 14 shows that increasing the concrete slab thickness decreases the concrete slab compressive stresses. Furthermore, it can be seen that the highest imposed load is achieved with the concrete slab thickness of $5 \mathrm{~cm}$, for which the whole concrete slab thickness is still under compression. With higher concrete slab thicknesses there is no increase in the loadbearing capacity anymore. The effective bending stiffness stagnates and starts to decrease with thicknesses higher than $5 \mathrm{~cm}$ because the concrete is defined to fail under tension. The coefficient of composite action, $\gamma$, is calculated only for the uncracked concrete slab thickness and decreases with higher concrete slab thicknesses. With increasing concrete slab thickness, the design bending moment is counterbalanced with inner bending moments rather than inner forces of the partial cross sections (timber joist cross-section and concrete slab cross-section). The increasing inner bending moments in the concrete slab results in concrete slab tensile cracking as concrete is considered to fail under tension. Another reason for the higher concrete slab thicknesses not resulting in higher maximum imposed loads is also the increasing self-weight of the floor. 
Table 14 - Results for »Ultimate limit state - Bending Final« and varying concrete slab thickness

\begin{tabular}{|c|c|c|c|c|c|c|c|c|}
\hline $\mathrm{h}_{\mathrm{c}}$ & $\mathrm{Q}$ & $\sigma_{\mathrm{c} . \text { top }}$ & $\sigma_{\mathrm{c}, \text { bot }}$ & $\mathrm{x}_{\mathrm{c}}$ & $(\mathrm{EI})_{\mathrm{ef}}$ & $\mathrm{K}$ & $\gamma$ & $\mathrm{G}$ \\
\hline$[\mathrm{cm}]$ & {$\left[\frac{\mathrm{kN}}{\mathrm{m}^{2}}\right]$} & {$[\mathrm{MPa}]$} & {$[\mathrm{MPa}]$} & {$[\mathrm{cm}]$} & {$\left[\mathrm{GN} \cdot \mathrm{cm}^{2}\right]$} & {$\left[\frac{\mathrm{kN}}{\mathrm{cm}^{2}}\right]$} & $/$ & {$\left[\frac{\mathrm{kg}}{\mathrm{m}^{2}}\right]$} \\
\hline 1.0 & 5.42 & -7.66 & -6.63 & 1.00 & 21.75 & 36.42 & 0.58 & 182.66 \\
\hline 2.0 & 5.62 & -5.63 & -3.71 & 2.00 & 24.63 & 36.42 & 0.41 & 207.66 \\
\hline 3.0 & 5.72 & -4.90 & -2.12 & 3.00 & 26.69 & 36.42 & 0.31 & 232.66 \\
\hline 4.0 & 5.80 & -4.64 & -1.03 & 4.00 & 28.51 & 36.42 & 0.25 & 257.66 \\
\hline 5.0 & 5.91 & -4.60 & -0.19 & 5.00 & 30.32 & 36.42 & 0.21 & 282.66 \\
\hline 6.0 & 5.86 & -4.55 & 0.00 & 5.09 & 30.56 & 36.42 & 0.19 & 307.66 \\
\hline 7.0 & 5.75 & -4.48 & 0.00 & 4.91 & 30.33 & 36.42 & 0.16 & 332.66 \\
\hline 8.0 & 5.63 & -4.40 & 0.00 & 4.75 & 30.17 & 36.42 & 0.15 & 357.66 \\
\hline 9.0 & 5.51 & -4.34 & 0.00 & 4.61 & 30.06 & 36.42 & 0.13 & 382.66 \\
\hline 10.0 & 5.38 & -4.28 & 0.00 & 4.48 & 30.00 & 36.42 & 0.12 & 407.66 \\
\hline
\end{tabular}

\subsection{Comparison of the Classic Timber Floor and the Timber-Concrete Composite Floor}

For easier comparison, we took the lowest maximum imposed loads of both floors (5.1. Timber Floor and 5.2. Timber-Concrete Composite Floor) and compared them in one diagram (Fig. 14).

The difference between the lowest maximum imposed loads of the two floors is higher for greater spans. The TCC floor proved its structural superiority compared to the timber floor, as its lowest maximum imposed load (load-bearing capacity) is higher for almost all spans. For the $2 \mathrm{~m}$ span, the timber floor has a higher load-bearing capacity, but this is a consequence of the fact that only the timber joists are used for the shear resistance of the TCC floor. If the concrete slab was also considered for the shear resistance, the results for the $2 \mathrm{~m}$ span would also be in favor of the TCC floor.

For the $5 \mathrm{~m}$ span the difference between the lowest maximum imposed loads is $\left(5.9 \frac{\mathrm{kN}}{\mathrm{m}^{2}}-2.2 \frac{\mathrm{kN}}{\mathrm{m}^{2}}\right)=3.7 \frac{\mathrm{kN}}{\mathrm{m}^{2}}$. Even if the floor filling of the timber floor (with an area weight of $1.0 \frac{\mathrm{kN}}{\mathrm{m}^{2}}$ ) was removed, the difference would still be $2.7 \frac{\mathrm{kN}}{\mathrm{m}^{2}}$. Interestingly, the most critical criteria for the timber floor are the serviceability criteria and on the other hand, ultimate criteria are most critical for the TCC floor. This is probably the consequence of the concrete slab contributing to the effective bending stiffness more than to the bending strength. 


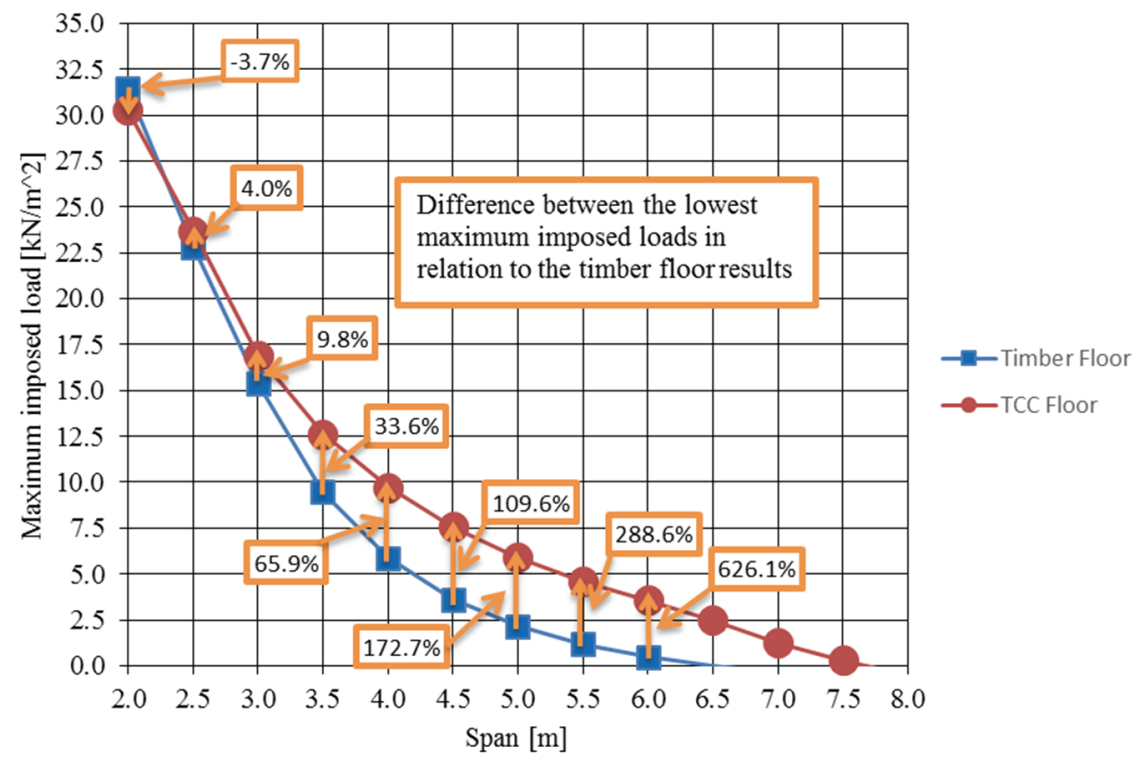

Fig. 14 - Comparison of the lowest maximum imposed load for the timber and TCC floor (the basis for the percent changes is the load-bearing capacity of the timber floor)

\section{CONCLUSION}

Firstly, floor structure evolution and timber floor types in Central Europe were briefly presented. The study showed that the timber floor filling presents a large part of the whole floor weight, which can be of high importance when reconstructing old timber floors. Moreover, the example from Slovenia explains how changes of building standards can cause that a floor is not in compliance with the valid building standards anymore. Although the filling removal may considerably lower the floor self-weight, the influence on other criteria should not be forgotten or disregarded. Especially the impact on the sound insulation should be controlled in the case of filling removal.

Further, timber floor strengthening techniques were presented, leading to the conclusion that numerous techniques differ only in the "strengthening target". They can strengthen the timber joists' compressive or tensile zone, moreover, they can also act as additional bending elements. Since it rarely happens (as in the case of apartment buildings) that the timber floor covers more rooms of one owner, the strengthening techniques should also be arranged regarding the preferable or required access side for the measure to be executed.

Despite many variants of old timber floors, the studied timber floor was declared as a classic timber floor and presented the basis of the numerical example, which showed that the loadbearing capacity of timber floors is usually limited with their serviceability criteria.

Thus, the standard timber floor, refurbished with a concrete slab, resulted in a timber-concrete composite floor and could meet the current building standard requirements. The calculations for the composite section showed the limitation of the load-bearing capacity (considering the 
ultimate bending criteria) with the timber tensile and bending strength. In addition, a calculation of the load-bearing capacity (considering the final ultimate bending criteria) for different concrete slab thicknesses was performed. It showed that a higher concrete slab thickness did not necessarily result in a higher load-bearing capacity. To increase the load bearing capacity further, strengthening of the timber joist tensile zone (or side) is needed. An example of this measure is the use of CFRP strips [28]. However, as CFRP strips negatively impact the timber floor appearance, more "transparent" strengthening techniques are favorable.

The findings of this article should encourage responsible authorities to preserve the originality of old timber floors or to re-build old timber floors in a modified way, similar to the timber-concrete composite section. Furthermore, other technical criteria, such as sound insulation, fire safety and thermal conductivity should be taken into account when planning timber floor renovation. Considering the results regarding structural calculation for the timber-concrete composite floor and the literature review it seems that this floor system has the potential to fulfill all relevant criteria.

\section{Conflict of Interest}

The authors declare that they have no conflict of interest.

\section{Acknowledgment:}

The authors acknowledge the financial support from the Slovenian Research Agency (research core funding No. P2-0129).

\section{References}

[1] Arnuga I (2010) Mehanska odpornost lesno-betonskega sovprežnega stropu [Mechanical resistance of a timber-concrete composite deck]. Univerza v Mariboru, Fakulteta za gradbeništvo

[2] Riggio M, Tomasi R, Piazza M (2014) Refurbishment of a traditional timber floor with a reversible technique: Importance of the investigation campaign for design and control of the intervention. International Journal of Architectural Heritage 8:74-93

[3] Gubana A (2015) State-of-the-Art Report on high reversible timber to timber strengthening interventions on wooden floors. Construction and Building Materials 97:25-33

[4] Yeoh D, Fragiacomo M, De Franceschi M, Heng Boon K (2010) State of the art on timber-concrete composite structures: Literature review. Journal of structural engineering 137:1085-1095

[5] Soriano FM, Pericot NG, Sierra EM (2016) Comparative analysis of the reinforcement of a traditional wood floor in collective housing. In depth development with cross laminated timber and concrete. Case Studies in Construction Materials 4:125-145 
[6] Branco JM, Descamps T, Tsakanika E (2018) Repair and Strengthening of Traditional Timber Roof and Floor Structures. In: Strengthening and Retrofitting of Existing Structures. Springer, pp 113-138

[7] Pech A, Kolbitsch A, Zach F (2007) Decken. Springer Science \& Business

[8] Graf IJ Integrale Holz-Beton-Verbundbrücken für die Landesgartenschau 2014 in Schwäbisch Gmünd

[9] Brunner M, Romer M, Schnüriger M (2007) Timber-concrete-composite with an adhesive connector (wet on wet process). Materials and structures 40:119-126

[10] Kolbitsch A (1989) Altbaukonstruktionen: Charakteristika Rechenwerte Sanierungsansätze. Springer Vienna

[11] Lißner K, Rug W (2013) Holzbausanierung: Grundlagen und Praxis der sicheren Ausführung. Springer-Verlag

[12] Furundžić B (1965) Zbirka tehnickih propisa u gradevinarstvu [Collection of technical regulations in civil engineering]. Građevinska Knjiga, Beograd

[13] International Organization for Standardization (1986) ISO 2103:1986 - Loads due to use and occupancy in residential and public buildings

[14] European Committee for Standardization. (2002) EN 1991-1-1: Eurocode 1: Actions on structures - Part 1-1: General actions - Densities,self-weight, imposed loads for buildings. CEN, Brussels

[15] Branco JM, Kekeliak M, Lourenço PB (2014) In-plane stiffness of traditional timber floors strengthened with CLT. In: Materials and Joints in Timber Structures. Springer, pp $725-737$

[16] Tajnik M, Premrov M, Dobrila P, Bedenik B (2011) Parametric study of composite Tbeam. Proceedings of the Institution of Civil Engineers-Structures and Buildings $164: 345-353$

[17] Premrov M, Dobrila P (2012) Experimental analysis of timber-concrete composite beam strengthened with carbon fibres. Construction and Building Materials 37:499506

[18] Faggiano B, Marzo A, Formisano A, Mazzolani FM (2009) Innovative steel connections for the retrofit of timber floors in ancient buildings: a numerical investigation. Computers \& Structures 87:1-13. https://doi.org/10/d5xs3b

[19] Costa A, Guedes JM, Varum H (2013) Structural rehabilitation of old buildings. Springer

[20] Piazza M, Baldessari C, Tomasi R, Acler E (2008) Behaviour of refurbished timber floors characterized by different in-plane stiffness. Structural Analysis of Historic Construction - D’Ayala \& Fodde (eds)

[21] Tomazevic M (2009) Stavbe kulturne dediscine in potresna odpornost: kaj smo se naucili? = Heritage masonry buildings and seismic resistance : what did we learn? Gradbeni vestnik 2009 
[22] Tomaževič M, Weiss P, Velechovsky T (1991) the influence of rigidity of floors on the seismic behaviour of old stone-masonry buildings

[23] Tomaževič M, Lutman M, Velechovsky T (1993) Aseismic strengthening of old stonemasonry buildings: is the replacement of wooden floors with RC slabs always necessary?

[24] Gattesco N, Macorini L (2014) In-plane stiffening techniques with nail plates or CFRP strips for timber floors in historical masonry buildings. Construction and Building Materials 58:64-76

[25] Brezar V (2011) Pragmatično graditeljstvo ali sindrom 4 metrov/Pragmatic construction or a 4-meter syndrome. Arhitektura, Raziskave 2011:85

[26] European Committee for Standardization. (2004) EN 1995-1-1: Eurocode 5: Design of timber structures - Part 1-1: General - Common rules and rules for buildings. CEN, Brussels

[27] European Committee for Standardization. (2004) EN 1992-1-1: Eurocode 2: Design of concrete structures - Part 1-1: General rules and rules for buildings

[28] Tajnik M, Dobrila P, Premrov M (2007) Analysis of composite T beam composed of timber, concrete and carbon strip. In: Proceedings of the 9th WSEAS international conference on Mathematical and computational methods in science and engineering. World Scientific and Engineering Academy and Society (WSEAS), pp 223-229 